\title{
Dylematy nauczyciela akademickiego kierującego seminarium magisterskim w ramach studiów tłumaczeniowych
}

\section{Dilemmas of academic teachers conducting MA seminars within translation studies}

\author{
Teresa Tomaszkiewicz \\ INSTYTUT FILOLOGII ROMAŃSKIEJ, UNIWERSYTET IM. ADAMA MICKIEWICZA \\ AL. NIEPODLEGŁOŚCI 4, 61-874 POZNAŃ \\ tomaszki@amu.edu.pl
}

\begin{abstract}
The following paper discusses the role of an MA seminar and an MA thesis in the process of education of professional translators who are more oriented toward gaining knowledge and skills instead of research activities. The Author, basing upon own experiences, aims to present dilemmas which academic teachers face while conducting such seminars as well as to explain how they can target students' actions, so they can combine research activities with professional practice as part of a given educational path.
\end{abstract}

\section{Kształcenie tłumaczy profesjonalnych w Europie - podstawowe założenia}

$\mathrm{Na}$ początku wypadałoby przypomnieć kilka może podstawowych wiadomości i stwierdzeń, które mimo swego banalnego charakteru stanowią fundament dalszych rozważań. Jest kwestią bezsporną, że Unia Europejska jest i chyba pozostanie organizacją wielojęzyczną i wielokulturową, a komunikacja między jej członkami jest zapewniona dzięki tłumaczeniom pisemnym i konferencyjnym. Do tego powołane są odpowiednie agendy, pracujące na rzecz m.in. Komisji Europejskiej i Parlamentu Europejskiego.

Poszerzanie ilości członków Unii Europejskiej doprowadziło do ciągle rosnącego zapotrzebowania na wykwalifikowanych tłumaczy konferencyjnych $\mathrm{z}$ jednej strony i pisemnych $\mathrm{z}$ drugiej. W momencie przystępowania nowych członków do UE z Europy centralnej i wschodniej 
okazało się, że kraje te nie dysponowały wcześniej, lub dysponowały w ograniczonej mierze, instytucjami kształcącymi tłumaczy zawodowych zgodnie z określonymi normami. Ta sytuacja doprowadziła do podjęcia intensywnych prac nad opracowaniem modelu kształcenia tego typu tłumaczy, a także do stworzenia sieci programów uniwersyteckich, które odpowiadają przyjętym normom jakości i mogą zapewnić dopływ tłumaczy do agend europejskich. Działania w tej kwestii były prowadzone paralelnie przez dwa niezależne środowiska:

- W 1997 roku Wspólna Agenda tłumaczeniowo konferencyjna Unii Europejskiej (European Commission's Joint Interpreting and Conference Service (SCIC) ${ }^{1}$ i Dyrekcja Generalna ds. Edukacji (Directorate General for Education (DGXXII) zainicjowały projekt pilotażowy stworzenia właśnie takiej sieci uniwersytetów kształcących tłumaczy konferencyjnych na poziomie magisterskim. Po kilku latach spotkań i dyskusji, 9.05.2001 podpisano oficjalne porozumienie o utworzeniu konsorcjum. W 2012 roku przekształcono to konsorcjum w Konsorcjum międzynarodowe, przyjmując jednocześnie jego Konstytucję.

- W kwestii kształcenia tłumaczy pisemnych, inicjatorem podobnych działań była Dyrekcja Generalna ds. Tłumaczenia dla Komisji Europejskiej z siedzibą w Brukseli. Pierwszym zadaniem stało się powołanie w 2007 platformy dyskusyjnej dla wielu podmiotów zajmujących się tłumaczeniem, w celu opracowania kryteriów programów kształcenia tłumaczy na najwyższym poziomie, co skutkowało utworzeniem w 2008 roku pierwszej sieci takich programów funkcjonujących w uniwersytetach europejskich : EMT (European Master's in Translation). Następne nabory miały miejsce w 2011-2013 i 2014-2018².

Programy te oczywiście nie są identyczne ponieważ :

- muszą być zgodne z normami krajowymi (np. w kwestii regulacji ministerialnych czy wydawania dyplomów),

- powinny odpowiadać zapotrzebowaniu lokalnych rynków pracy,

- powinny być zgodne z tradycją danego uniwersytetu,

- powinny odpowiadać możliwościom kadry nauczającej,

- i kryteriom organizacyjnym danej jednostki kształcącej,

- a do tego, możliwościom technicznym danej jednostki.

Zresztą kryteria naboru poszczególnych programów do ww. sieci również ulegają ewolucjom, ze względu na zmieniające się konteksty pracy tłumaczy, a co za ty idzie na zmiany oczekiwanych przez pracodawców kompetencji przyszłych pracowników.

\footnotetext{
${ }^{1}$ Wieccej informacji na stronie : https://ec.europa.eu/info/departments/interpretation en

2 Więcej informacji na stronie : https://ec.europa.eu/info/resources-partners/europeanmasters-translation-emt_en
} 
Teresa Tomaszkiewicz: Dylematy nauczyciela akademickiego kierującego seminarium magisterskim $w$ ramach studiów thumaczeniowych

Aby zilustrować to twierdzenie możemy posłużyć się jednym z wielu przykładów. W obowiązującym od 2009 tzw. „kole kompetencji”, w które powinien być wyposażony przyszły tłumacz zawodowy, kształcony $\mathrm{w}$ kontekście EMT, wymieniano następujące:

- KOMPETENCJE ZWIAZZANE ZE ŚWIADCZENIEM USŁUG TŁUMACZENIOWYCH: wymiar KONTAKTÓW MIĘDZYLUDZKICH

- KOMPETENCJE ZWIĄZANE ZE ŚWIADCZENIEM USŁUG TŁUMACENIOWYCH: wymiar PRODUKT

- KOMPETENCJE JEZZYKOWE

- KOMPETENCJE INTERKULTUROWE : wymiar SOCJOLINGWISTYCZNY

- KOMPETENCJE INTERKULTUROWE : wymiar TEKSTOWY

- KOMPETENCJE TEMATYCZNE

- KOMPETENCJE TECHOLOGICZNE (umiejętność posługiwania się narzędziami informatycznymi) 3

W latach 2016-2018 prowadzone były prace nad inaczej sformułowaną listą obowiązujących kompetencji, bardziej odpowiadających wyzwaniom współczesnego rynku pracy4:

- LANGUAGE AND CULTURE (TRANSCULTURAL AND SOCIOLINGUISTIC AWARENESS AND COMMUNICATIVE SKILLS)

- TRANSLATION (STRATEGIC, METHODOLOGICAL AND THEMATIC COMPETENCE)

- TECHNOLOGY (TOOLS AND APPLICATIONS)

- PERSONAL AND INTERPERSONAL COMPETENCE

- SERVICE PROVISION 5

W tym nowym podejściu, na przykład bardzo duży nacisk położony jest na kształcenie kompetencji technologicznych, umiejętności posługiwania się nowymi narzędziami informatycznymi wspomagającymi pracę tłumacza i na wykorzystywanie tłumaczenia automatycznego wspomaganego przez post-edycję, czy na kształcenie nowych umiejętności typu lokalizacja lub audiodeskrypcja. Niemniej we wszystkich tych programach, które mają

3 EMT (European Master's in Translation), \& Gambier, Y. (2009). « Compétences pour les traducteurs professionnels, experts en communication multilingue et multimédia. » Tekst dostępny $\mathrm{w}$ Internecie $\mathrm{w}$ formie Pdf

${ }^{4}$ Ta nowa lista została ogłoszona 14.09.2018 i znajduje sie pod adresem elektronicznym: https://ec.europa.eu/info/sites/info/files/emt_competence_fwk_2017_en_web.pdf

Ponieważ nie ma wersji polskiej tego dokumentu, dlatego przedstawiam tę listę w roboczym języku angielskim.

${ }^{5}$ W tym momencie chciałabym podkreślić, że celem tego artykułu nie jest odnoszenie się do wielu bardzo wartościowych prac, powstatych na gruncie polskim lub w innych krajach, skupionych na kompetencjach tłumacza, a tylko i wyłacznie przytoczenie problematyki kompetencji w ściśle określonym kontekście sieci EMT. 
kształcić takie czy inne kompetencje zawodowe, powinna być zachowana pewna ogólna struktura, która musi uwzględnić trzy podstawowe bloki:

- Kształcenie językowo-tłumaczeniowe;

- Kształcenie zawodowe;

- Kształcenie akademickie;

W dalszej części chcę się skupić na tym ostatnim aspekcie.

\section{Kształcenie akademickie}

W kontekście polskich studiów tłumaczeniowych na poziomie magisterskim, kształcenie akademickie obejmuje, obok wykładów z teorii tłumaczenia czy konwersatorium specjalistycznego, seminarium magisterskie, wynoszące 120 godzin realizowanych $\mathrm{w}$ ciągu dwóch lat $\mathrm{i}$ kończące się zredagowaniem przez studentów pracy magisterskiej. Praca ta jest przygotowywana pod nadzorem promotora, przez niego dopuszczana do recenzji innego naukowca i ostatecznie oceniana przez promotora i recenzenta, co w kontekście obu pozytywnych recenzji doprowadza do egzaminu magisterskiego. Wobec różnych rozwiązań $\mathrm{w}$ uniwersytetach europejskich, o czym będzie mowa dalej, należy z całą mocą podkreślić, że w Polsce przedstawienie tej pracy jest obowiązkowe, aby można było otrzymać dyplom magistra. Niemniej, w różnych uniwersytetach europejskich, również w tych należących do sieci EMT, definicje dotyczące tego, czym jest, nazwijmy ją „pracą końcową wieńcząca studia magisterskie", są bardzo zróżnicowane.

Wyżej wspomniałam, że instrukcje dotyczące przygotowania dokumentacji przystąpienia do sieci EMT bardzo precyzyjnie opisują rodzaj kompetencji, których należy nauczać przyszłych tłumaczy, ale pomijają, bardziej lub mniej świadomie, wytyczne dotyczące zakresu, formy, celów tej pracy badawczej, która ma za zadanie „dopełnienie wymiaru akademickiego" tego kształcenia zawodowego.

W artykule z 2017 roku, który dostępny jest w Internecie ${ }^{6}$, „European Masters in Translation. A comparative study", Antony Pym i Ester TorresSimón przeprowadzają analizę ilościową i jakościową programów zrzeszonych w sieci EMT, aby wykazać czasem znaczące różnice między nimi. Obok różnych parametrów branych pod uwagę pojawia się również parametr teoretyczny, czyli wykłady z teorii tłumaczenia i sposób włączania studentów w prace badawcze danej jednostki. Jednym z elementów włączania studentów $\mathrm{w}$ działania badawcze może być przedstawienie $\mathrm{w}$ pracy magisterskiej wyników przeprowadzonych przez nich badań. Ten model nie jest jednak realizowany we wszystkich uniwersytetach należących do sieci EMT. Odwołując się do wspomnianego artykułu Pym/Torres, należy przyjąć, że 94\% analizowanych programów EMT przyznaje punkty ECTS, w

\footnotetext{
${ }^{6} \mathrm{http}: / /$ www.academia.edu/31635052/European_Masters_in_Translation._A_comparativ e_study
} 
Teresa Tomaszkiewicz: Dylematy nauczyciela akademickiego kierujacego seminarium magisterskim $w$ ramach studiów thumaczeniowych

końcowym semestrze studiów, za coś, co nazwane jest przez autorów: „research-oriented credits”. Niemniej w tej analizie podkreśla się, że te działania badawcze są bardzo zróżnicowane, jeżeli chodzi o wymogi różnych uniwersytetów. Właściwie można stwierdzić, że punkty ECTS za działania nazwane „research-oriented credits” są przyznawane za różne osiągnięcia nie zawsze mające charakter naukowy. Na przykład:

- w niektórych uniwersytetach (we Włoszech) te punkty ECTS mają status opcjonalny;

- w innych chodzi o opracowanie własnego tłumaczenia komentowanego;

- w jeszcze innych projekt badawczy nie dotyczy przekładoznawstwa a literatury porównawczej (Bułgaria);

- pewne uniwersytety pozostawiają studentom możliwość wyboru między pracą badawczą (magisterską) a egzaminem państwowym;

- kilka uniwersytetów francuskich proponuje pracę pisemną opartą na doświadczeniach zdobytych podczas obowiązkowych praktyk zawodowych;

- jeszcze inne uniwersytety zakładają możliwość wyboru przez studentów między redakcją pracy magisterskiej a odbyciem praktyk zawodowych;

- w niektórych, praca końcowa ma formę eseju 10-15 stronicowego, przygotowywanego w czasie wakacji, w ramach pracy własnej, po ukończeniu podstawowego programu zawodowego;

- istnieją uniwersytety, w których studia magisterskie trwają 1 rok, 1,5 roku lub jak w Polsce 2 lata.

Te różnice są zdecydowanie ważne, bo pokazują, że uniwersytety europejskie nie mają wypracowanego wspólnego stosunku do pracy wieńczącej studia magisterskie i do jej roli w całym procesie kształcenia. O tym też świadczy rozpiętość wagi procentowej przyznawanej tej pracy w postaci punktów ECTS, w stosunku do wszystkich punktów przyznawanych tym studiom. W analizowanych programach te proporcje rozkładają się $\mathrm{w}$ sposób nieproporcjonalny : od 2\% (Praga) do 38\% (Porto)7.

$\mathrm{W}$ tym momencie należy oczywiście poczynić pewne zastrzeżenia $\mathrm{w}$ stosunku do analizy przeprowadzonej przez autorów cytowanego tekstu. Najlepszym dowodem na brak staranności w pozyskiwaniu przez nich danych jest stwierdzenie, że programy tłumaczeniowe, oferowane w UAM nie uwzględniają przedmiotów teoretycznych ani pracy magisterskiej na koniec studiów, co przecież w kontekście polskim jest niemożliwe. Inne przytaczane dane też czasem nie pokrywają się $\mathrm{z}$ rzeczywistością, co oprotestowali członkowie EMT. Niemniej, stwierdzając pewną ignorancję autorów wspomnianego artykułu, należy oddać im rację, kiedy twierdzą, że tzw. „seminarium magisterskie” i „praca magisterska” nie są jasno zdefiniowane w kontekście studiów magisterskich w Europie. Nie zmienia

${ }^{7}$ Wszystkie ww. dane przytaczam za wspomnianym artykułem Pym/ Torres (2017). 
to faktu, że ta bliżej nieokreślona praca pozostaje podstawą przyznania dyplomu na koniec studiów, zarówno w Polsce jak i w innych krajach europejskich.

Konkludując, możemy w różnych programach kształcenia tłumaczy zawodowych proponować różne zajęcia i działania praktyczne, ale nie możemy pomijać wagi seminarium magisterskiego i roli pracy magisterskiej w całym tym procesie kształcenia.

W konsekwencji, po raz pierwszy w tym omówieniu chcę nawiązać do haseł przewodnich tej publikacji, NORMA A UZUS :

- normą jest, że europejskie programy kształcenia tłumaczy kończą się jakąś pracą indywidualną, która w zależności od kraju lub uniwersytetu, ma charakter bardziej lub mniej badawczy, za którą przewidziane są punkty ECTS;

- uzus wskazuje na to, że formy tej pracy są zdecydowanie zróżnicowane w różnych uniwersytetach i ostatecznie mają różne cele.

Te stwierdzenia pozwalają na określenie dylematów, z którymi musi się zmierzyć kierownik seminarium magisterskiego prowadzonego $\mathrm{w}$ ramach studiów kształcących tłumaczy zawodowych na polskich uczelniach wyższych. Chciałabym sprowadzić te dylematy do kilku fundamentalnych pytań:

- Jaka jest rola działań badawczych studentów w całym kontekście magisterskich studiów zawodowych, które według nich powinny mieć przede wszystkim charakter praktyczny?

- Jak studenci, gremialnie nastawieni na studia przygotowujące ich do konkretnych zawodów, odbierają konieczność skupienia się na działaniu badawczym, które w ich ocenie nie przekłada się automatycznie na kompetencje stricte zawodowe?

- Jak wykazać, że czasem pogłębiona refleksja nad pewnymi mechanizmami teoretycznymi może przyczynić się do większej wydajności zawodowej ?

- Jak skłonić studentów do tego intelektualnego wysiłku, aby nie postrzegali go jako czas stracony?

- Co zrobić, aby to działanie twórcze, stało się ich celem w ciągu dwóch lat i pozostało elementem znaczącym w ich przyszłym życiu zawodowym?

\section{Definicja seminarium magisterskiego}

W kontekście tych wszystkich, wymienionych wyżej dylematów należy sformułować jakąś definicję, tego czym w naszym kontekście miałoby być seminarium magisterskie i praca magisterska ${ }^{8}$. Wszystkie przytoczone

${ }^{8}$ Mogloby sie wydawać, że to już dawno zostało określone, chociażby w efektach
ksztatcenia w Krajowych Ramach Kwalifikacji. Niemniej, chcę podkreślić, że omawiam tu 


\section{Teresa Tomaszkiewicz: Dylematy nauczyciela akademickiego kierujacego seminarium magisterskim $w$ ramach studiów thumaczeniowych}

opinie skłaniają do stwierdzenia, że każde uniwersyteckie kształcenie zawodowe ma dwie strony medalu:

- pragmatyczną: nauczanie pewnych kompetencji i umiejętności praktycznych;

- i akademicką : nauczanie pogłębionej refleksji nad przedmiotem studiów, rozwijanie intelektu, nauczanie właściwego rozumowania, które powinno prowadzić do praktycznych rozwiązań, wykorzystywania zależności przyczynowo-skutkowych, umiejętności wyciągania wniosków, umiejętności obrony własnych sądów. Tych umiejętności powinien, między innymi, nabywać student w ramach seminarium magisterskiego.

Czym zatem jest seminarium magisterskie? Jakie są jego role? Sylabus takiego seminarium powinien uwzględniać następujące działania:

- Zmobilizowanie studentów do zapoznawania się $\mathrm{z}$ tekstami naukowymi i do potraktowania ich jako inspirację do dalszych badań ;

- Zmobilizowanie studentów do wyciągania wniosków z lektur punktowych związanych z planowanym badaniem;

- Określenie celów badania i zamierzonych sposobów działania;

- Zdefiniowanie problemów badawczych i metodologii badawczej;

- Pomoc w określeniu zakresu planowanych badań i w dobraniu odpowiedniego korpusu do ich przeprowadzenia;

- Pomoc w obronie przedstawionych tez;

- Pomoc w redakcji tekstu końcowego.

- Ogólnie nauczanie myślenia, formułowania na piśmie określonej argumentacji i obrony własnych opinii.

W tym kontekście możemy zadać sobie pytanie, jaka zatem jest rola osoby kierującej seminarium magisterskim $w$ ramach studiów tłumaczeniowych. Szerokie opracowania na ten temat są raczej rzadkością9, dlatego taka osoba często działa intuicyjnie, musząc zmierzyć się z nowymi dylematami:

- Czy w grupie seminaryjnej chodzi o pewną współpracę, opracowywanie pewnych lektur wspólnie, dyskusję nad możliwymi rozwiązaniami, czy bardziej chodzi o indywidualną współpracę opiekuna i studenta typu „tutorial”?

kontekst studiów zawodowych, do których sami studenci mają inny stosunek, niż do studiów ogólnouniwersyteckich.

9 Pewna dyskusja dotycząca użyteczności pracy magisterskiej w kontekście uniwersyteckich studiów zawodowych była przeprowadzona na lamach Forum Akademickiego: https://prenumeruj.forumakademickie.pl/fa/2007/o7-08/prace-magisterskie-za-i-przeciw/, niemniej tego typu rozważania są raczej rzadkością, nie tylko w Polsce. 
- Czy tematyka prac magisterskich ma być powiązana z zajęciami praktyki tłumaczeniowej, czy ma stanowić odrębne działanie $\mathrm{w}$ ramach oferowanych studiów?

- Czy należy różnicować tematykę prac studentów realizujących program tłumaczenia konferencyjnego od tych realizujących program tłumaczenia pisemnego?

- I najważniejsze pytanie, które wiąże się z poprzednimi : na ile studenci powinni/mogą być włączeni w prace badawcze prowadzone w danym Zakładzie czy przez opiekuna, realizując jakiś ich element, co jest ogólnie zalecane w różnych systemach oceniania programów studiów jako takich? W tym momencie mamy do czynienia $\mathrm{z}$ problemem praw autorskich, ale to odrębna sprawa, której tu nie będę rozwijać, bo temu należało by poświęcić odrębną dyskusję.

\section{Własne doświadczenia ${ }^{10}$}

Prowadzę seminaria magisterskie od 25 lat, ale w tym co przestawię poniżej biorę pod uwagę ostatnie 18 lat, w których zaczął pojawiać się Internet, kiedy powoli dostępne zaczynały być banki danych i kiedy zaczęłam się przymierzać do stworzenia prawdziwych studiów tłumaczeniowych, odpowiadających normom europejskim.

Muszę stwierdzić, że mimo bardzo istotnych zmian w tym czasie, dotyczących zasobów danych, możliwości technicznych analizy, nowych wyzwań stojących przed translatoryką światową, działania i postawy studentów na seminarium magisterskim nie ulegają wielkim przeobrażeniom. W większości przypadków prace opierane są na takich czy innych korpusach. Niemniej, generalnie można zaobserwować zasadniczo dwie postawy badawcze:

- studenci mają jakiś pomysł na przeanalizowanie pewnego zagadnienia badawczego i starają się dobrać korpus do realizacji tego celu,

- ale częściej, mając dostęp do jakiegoś korpusu, zastanawiają się, „co z tym zrobić?”.

- Trzecią możliwością, którą również praktykowałam w dwóch projektach naukowych, jest włączenie studentów do badań, w których korpusy były w pewnym sensie „narzucone”, a metodologia sprowadzała się do komentarzy własnego tłumaczenia ${ }^{11}$.

Generalnie, w ostatnich 18 latach kierowałam 173 pracami magisterskimi, z czego 171 opierało się na analizie różnych korpusów, w

${ }^{10}$ Czesść z przedstawionych niżej danych była już prezentowana $w$ trzech moich artykułach Tomaszkiewicz: 2015 a 2015b, 2015c, ale tutaj jest zmodyfikowana i poszerzona o dane $z$ lat 2014-1017.

11 Wyniki tych doświadczeń zostały przedstawione $w$ kilku moich publikacjach: Tomaszkiewicz: 2008, 2009, 2012, 2013, dlatego w niniejszym zestawieniu nie rozwijam szerzej wyników tego eksperymentu. 
Teresa Tomaszkiewicz: Dylematy nauczyciela akademickiego kierujacego seminarium magisterskim $w$ ramach studiów thumaczeniowych

większości przypadków kompletowanych/dobieranych przez samych studentów ${ }^{12}$. Korpusy te ogólnie można podzielić na literackie $45 \%$ i nieliterackie $55 \%$.

\subsection{Korpusy literackie}

Wśród analizowanych tekstów literackich większość stanowią powieści, nowele zarówno współczesne, jak i starsze średniowieczne, romantyczne, dziewiętnastowieczne, stanowiące ok. 66\% korpusów literackich. 6\% tych tekstów, to teksty oper lub musicali. Do tego należy dodać teksty poetyckie, piosenki (6\%), teksty literatury dziecięcej (5\%), sztuki teatralne (9\%). Do tej kategorii można również zaliczyć teksty biblijne (4\%), ponieważ wykazują wiele cech stylistycznych porównywalnych z tekstami literackimi.

Przykładowa, analizowana na bazie tych korpusów tematyka, to transfer różnych figur stylistycznych na poziomach: paradygmatycznym (metafory, personifikacje...), syntagmatycznym (apostrofy, powtórzenia, przeformułowania), fonetycznym (asonanse, aliteracje...); transfer komizmu, neologizmów itp.

Z drugiej strony komizm, który może być też analizowany na bazie korpusów nieliterackich (prasa, dzieła audiowizualne), natomiast formacje neologiczne mogą dotyczyć również języków specjalistycznych czy prasy. Tymczasem korpusy literackie pozwalają na refleksję nad prototypami tekstowymi : narracyjnymi, opisowymi czy dialogowymi. Z drugiej strony 17\% korpusów literackich zostało wykorzystanych do badania transferów leksykalnych czy morfologiczno-składniowych.

Jeszcze inna tematyka analizowana przy pomocy tekstów literackich, ale również audiowizualnych, to różnego rodzaju stylizacje: archaiczna, dialektalna, język subkultur młodzieżowych, język erotyczny itd. (15\%).

W większości przypadków chodziło o korpusy dwujęzyczne polskofrancuskie, ale również trzyjęzyczne : polsko-francusko-hiszpańskie; polsko-francusko-angielskie czy polsko-francusko-niemieckie.

W tym momencie chciałabym podkreślić, że wybranie odpowiedniego korpusu nie determinuje rodzaju refleksji naukowej nad konkretnie sformułowanym problemem badawczym.

\subsection{Korpusy nieliterackie}

Jeżeli chodzi o korpusy nieliterackie, to jak było wyżej powiedziane, stanowiły one materiał badawczy 55\% opisywanych prac magisterskich. Ich charakter jest bardzo zróżnicowany, ponieważ chodzi zarówno o teksty

12 Jeżeli chodzi o zastosowanie analizy korpusów $w$ badaniach przekładoznawczych $i$ językoznawczych, to możemy się odwołać na przykład do : Bocquet (2007), Vetulani (2013), Wecksteen (2007). 
pisemne, ustne, mieszane, które łączą stylistykę języka mówionego i pisemnego, a także teksty werbo-wizualne, w których dodatkowo występują elementy semiotyczne (gesty, mimika, obrazy, ikony, jak chociażby $\mathrm{w}$ tłumaczeniu audiowizualnym). Do tej kategorii należy również dołączyć teksty paralelne. Może wyliczenie tych różnych kategorii tekstów nie stanowi jakiegoś novum, ale interesujące jest przedstawienie pewnych statystyk dotyczących preferencji studentów w dobieraniu różnych korpusów przeznaczonych do analizy.

\subsubsection{Teksty specjalistyczne}

Pisemne teksty specjalistyczne stanowią 30\% wszystkich korpusów nieliterackich. Niemniej pojęcie języków specjalistycznych, czy tekstów specjalistycznych jest bardzo szerokie i może być analizowane w różnoraki sposób, dlatego przedstawiam pewne statystyki orientacyjne pokazujące pewne preferencje studentów, jeżeli chodzi o wybierane dziedziny ${ }^{13}$ : prawo (11), turystyka (4), a dalej w mniejszej ilości ekonomia (3), medycyna (3), technika (3), muzyka (2), kościół (2), tortury (1), marynarka (1), rybołówstwo (1), łowiectwo (1), wojskowość (1). 15 z tych prac ma charakter badań terminologicznych, a pozostałe skupiały się również na aspektach morfologiczno-składniowych i stylistycznych czy ich wymiarze semiologicznym.

\subsubsection{Teksty prasowe}

Drugą grupą tekstów, które stanowią materiał faktograficzny do tworzenia korpusów są teksty prasowe $(17 \%-20 \%)$. Ta kategoria $\mathrm{z}$ definicji jest bardzo zróżnicowana, ponieważ chodzi o teksty polityczne, prasę kobiecą, popularno-naukową, różne formy reklamy, ale również o modele tekstów prasowych (telewizyjnych) czy o teksty paralelne, funkcjonujące w wielu społeczeństwach, na zasadzie pewnych skostniałych prototypów, charakteryzujących się podobną strukturą i określonymi stereotypowymi wyrażeniami. Obok niektórych tekstów prasowych spełniających warunki modeli tekstów, można tu zaliczyć innego rodzaju formy jak przepisy kulinarne, nekrologi, instrukcje obsługi, ogłoszenia drobne czy umowy prawa cywilnego. Tego typu modele istnieją również w kontekście tłumaczenia audiowizualnego, jak chociażby dzienniki telewizyjne, talkshow, prognozy pogody itp.

\footnotetext{
${ }^{13}$ W tym przypadku podaję ilość prac opartych na korpusach należacych do danej dziedziny wiedzy.
} 
Teresa Tomaszkiewicz: Dylematy nauczyciela akademickiego kierującego seminarium magisterskim $w$ ramach studiów thumaczeniowych

\subsubsection{Teksty audiowizualne}

Generalnie można stwierdzić, że to odrębna kategoria korpusów, dość zróżnicowana, której podstawę stanowią filmy i inne teksty audiowizualne (TV, Internet). Niemniej studenci nie unikali również nowych wyzwań w tej dziedzinie: tłumaczenie $\mathrm{w}$ formie audiodeskrypcji (4 prace) i tłumaczenie $\mathrm{w}$ formie podpisów dla niesłyszących (2 prace). Jest sprawą ewidentną, że analiza tych korpusów musi uwzględniać ich wymiar semiologicznych tych tekstów, co również dotyczy następnej kategorii.

\subsubsection{Teksty werbo-wizualne $\mathrm{z}$ dominacja elementów semiotycznych}

Do tej kategorii należą oczywiście teksty audiowizualne, o których była mowa wyżej, ale również prasowe, instruktażowe typu instrukcje obsługi, analizowane z punktu widzenia relacji między warstwą słowną a ikoniczną (obrazy, fotografie, grafiki, ikony, wymiar mimiczno gestykulacyjny komunikacji) w transferze informacji. Zagadnienia te wchodzą w sferę tłumaczenia intersemiotycznego. Korpusy te stanowią 8\% wszystkich tekstów nieliterackich.

\subsubsection{Korpusy ustne}

Korpusy ustne to nagrania audialne lub audiowizualne codziennych konwersacji, wywiadów, wystąpień polityków czy innych specjalistów tłumaczonych konsekutywnie lub symultanicznie. Przedmiotem różnych prac była między innymi analiza wyrażeń rytualnych $\mathrm{w}$ codziennych konwersacjach, strategie przekonywania, realizacja stereotypowych aktów mowy typu „przeprosiny”, „oferty”, „powitania”. W trzech pracach analizowano zagadnienia dydaktyki tłumaczenia konsekutywnego lub konferencyjnego, w jednej różne aspekty tłumaczenia a-vista. Odrębne zagadnienia dotyczyły przejścia od kodu ustnego do pisemnego podczas tłumaczenia w formie napisów.

\subsubsection{Tłumaczenie automatyczne}

Mimo że jest to tematyka szeroko dyskutowana $\mathrm{w}$ kręgach przekładoznawców i mimo moich zachęt do jej podjęcia, w tym zakresie powstało tylko 6 prac. Niemniej, w ostatnich dwóch latach zainteresowanie tłumaczeniem maszynowym wzrasta, szczególnie w kontekście post-edycji, 
a także analizy błędów tłumaczeniowych. Te ostatnie dotyczą wszystkich kategorii korpusów przedstawionych wyżej.

\section{Podsumowanie}

Można powiedzieć, że może te tematyki nie zawsze są oryginalne, choć każdy nowy korpus książkowy, numeryczny, multimedialny, wielojęzykowy, wielosemiotyczny przynosi nowe odkrycia i nowe obserwacje. Jednak cały czas pozostaje ten fundamentalny dylemat : jakie są cele nadrzędne pracy magisterskiej, w kontekście kształcenia zawodowego. Czy należy zmuszać studentów do jej pisania, kiedy może nie widzą od razu bezpośredniego związku z wykonywaniem zamierzonego zawodu, czy może $\mathrm{z}$ niej zrezygnować, co często jest postulatem zarówno studentów jak i wykładowców ${ }^{14}$.

Otóż osobiście widzę ważne cele tej aktywności w ramach studiów tłumaczeniowych. W opisie kompetencji, których powinniśmy nauczać $\mathrm{w}$ ramach programów, o czym była wyżej mowa, zmienia się podejście do nauczania języków jako takich. Zakłada się, że student magisterskich studiów tłumaczeniowych musi mieć już świetnie opanowane tzw. „języki robocze”, co należy zweryfikować podczas naboru. Doświadczenie jednak uczy, że to nie jest zawsze prawda, dlatego uważam, że redagowanie pracy magisterskiej w języku obcym może przyczynić się do polepszenia i opanowania w sposób zadowalający języka pisemnego, zarówno ojczystego jak i obcego (obcych). To również szansa opanowania / utrwalenia technik argumentacyjnych.

Dokładniejsza analiza kompetencji, związanych $\mathrm{z}$ kompetencjami tłumaczeniowymi zakłada nabycie następujących umiejętności15:

- Analizy różnych typów dokumentów.

- Streszczania, przeformułowania, restrukturyzacji tekstu przy użyciu komunikacji pisemnej lub ustnej.

- Oceny jakości i użyteczności pozyskiwanych informacji.

- Nabywania, rozwijania, systematyki różnych dziedzin wiedzy, posługując się różnymi konceptami, metodami rozumowania, standardami prezentacji.

- Rozpoznawania i posługiwania się różnymi stylami tekstów.

- Redagowania różnego rodzaju tekstów w zależności od kontekstu komunikacyjnego.

\footnotetext{
14 Powracam tu do dyskusji na łamach Forum Akademickiego, o czym wspominałam wcześniej : https://prenumeruj.forumakademickie.pl/fa/2007/o7-08/prace-magisterskie-za-i-przeciw/

15 Caty dokument dotyczący pożąanych kompetencji nauczanych $w$ ramach studiów tlumaczeniowych jest dostęny pod następujacym adresem, który podany byt w przypisie 3 : https://ec.europa.eu/info/sites/info/files/emt_competence_fwk_2017_en_web.pdf
} 
Teresa Tomaszkiewicz: Dylematy nauczyciela akademickiego kierującego seminarium magisterskim $w$ ramach studiów thumaczeniowych

- Analizowania i obrony własnych wyborów translatorskich używając właściwego metajęzyka i odwołując się do właściwych podejść teoretycznych.

- Umiejętności korekty własnej pracy i pracy innych zgodnie ze standardami i kryteriami jakości.

\section{Czyż tych umiejętności nie nauczamy również w kontekście seminarium magisterskiego?}

Właśnie $\mathrm{w}$ ramach seminarium magisterskiego uczymy studentów stawiania problemów, rozwiązywania ich, planowania działań w czasie, samodyscypliny, pozyskiwania informacji, myślenia, porządkowania, hierarchizowania. Tak powinny być sformułowane efekty tego kształcenia, które na równi z przedmiotami praktycznymi, przygotowuje studentów do wykonywania zawodu, niekoniecznie tylko i wyłącznie tłumacza. 


\section{Investigationes Linguisticae, vol. XXXIX}

\section{Bibliografia}

Ballard, M. et Pineira-Tresmontant, C. (Ed). 2007. Les corpus en linguistique et en traductologie. Arras : Artois Presses Université Traductologie.

Bocquet, $\mathrm{Cl}$. 2007. D'un corpus pour la traduction à un corpus pour une véritable histoire de la traduction. w: M. Ballard et C. Pineira-Tresmontant (Ed). Les corpus en linguistique et en traductologie. Arras : Artois Presses Université Traductologie.

EMT (European Master's in Translation), \& Gambier, Y. (2009). " Compétences pour les traducteurs professionnels, experts en communication multilingue et multimédia. » Tekst dostępny w Internecie w formie Pdf

Pym, A., Torres-Simón, E. 2017. European Masters in Translation. A comparative study,

http://www.academia.edu/31635052/European_Masters_in_Translation._ A_comparative_study

Tomaszkiewicz, T. 2008. Transfert de la littérature acadienne en Pologne : bilan d'une expérience traductologique et didactique. $\mathrm{w}$ : Alternative francophone Vol.1,No1(2008)

http://ejournals.library.ualberta.ca/index.php/af/issue/current . pp. 98-118.

Tomaszkiewicz, T. 2009. Granice przekładalności współczesnej literatury akadyjskiej w świetle myśli Olgierda Wojtasiewicza. w: K. Hejwowski, A. Szczęsny, U. Topczewska (Ed.) : 50 lat polskiej translatoryki. Warszawa: ILS, pp.163-174.

Tomaszkiewicz, T. 2012. Croisement des langues et des cultures dans la traduction. w: A. Kacprzak, A. Konowska, M. Gajos (Ed.) Pluralité des cultures : chances ou menaces? Analyses linguisitiques et didactiques, pp.275-285.

Tomaszkiewicz, T. 2013. Traduction et reception des littératures minoritaires en tant que dialogue intercultural horizontal" w: A. Bueno, M.A. Vega (Ed) Traducción y humnismo, Bruxelles : Les Éditions du Hasard, pp.175-193

Tomaszkiewicz, T. 2015a. Les corpus dans le cadre de la maîtrise en traduction. w : M.T. Sánchez [et al.]. (Ed) Metodología y aplicaciones en la investigación en traducción e interpretación con corpus = Methodologies and applications in corpus-based and corpus-driven Translation and Interpreting research. Valladolid : Ediciones Universidad de Valladolid, 1 DVD - (Lingüística y Filología 83), pp. 357-371.

Tomaszkiewicz, T. 2015b. Rôle de l'analyse textuelle dans le cadre de la maîtrise en traduction. Svĕt Literatury/ Le Monde de la Littérature : Analyse de texte- Intertextualité. Praga : Faculté Philosophique de l'Université Charles à Prague, pp. 185-195.

Tomaszkiewicz, T. 2015c. La compétence linguistique vs d'autres compétences requises dans la formation professionnelle des traducteurs sur l'exemple polonais. Neofilolog, no. 44/1, pp. 91-113.

Vetulani, G. 2013. Problemy i korzyści wynikające z automatycznego przetwarzania korpusów - na przykładzie badań z zakresu predykacji rzeczownikowej w języku polskim. w: D. Śliwa (Ed.) Roczniki Humanistyczne, z. 8, Lingwistyka korpusowa i translatoryka. pp. 13-24.

Wecksteen, C. 2007. Le corpus en traductologie : un moyen d'observation pour une approche réaliste de la traduction : application à quelques phénomènes connotatifs. w: M. Ballard et C. Pineira-Tresmontant (Ed) Les corpus en linguistique et en traductologie. Arras: Artois Presses Université Traductologie. pp. 261-282. 
Teresa Tomaszkiewicz: Dylematy nauczyciela akademickiego kierującego seminarium magisterskim $w$ ramach studiów thumaczeniowych

Źródła elektroniczne :

http://ec.europa.eu/dgs/translation/programmes/emt/index_en.htm

https://ec.europa.eu/emt

https://ec.europa.eu/info/sites/info/files/emt_competence_fwk_2017_en_web. pdf

https://ec.europa.eu/info/departments/interpretation_en

Forum Akademickie: https://prenumeruj.forumakademickie.pl/fa/20o7/o7o8/prace-magisterskie-za-i-przeciw/ 